\title{
ИСТОРИЯ HISTORY
}

DOI: $10.18287 / 2542-0445-2020-26-3-8-15$ УДК 94(510)(091)

(c) () Научная статья / Scientific article
Дата: поступления статьи / Submitted: 11.05.2020 после рецензирования / Revised: 25.07.2020 принятия статьи / Accepted: 28.08.2020

С.Б. Макеева

Иркутский государственный университет, г. Иркутск, Российская Федерация E-mail: msbmag9581@yandex.ru. ORCID: https://orcid.org/0000-0003-2953-0411

\section{Научное обоснование стратегии регионального развития КНР во второй половине XX века (на материале работ китайских экономистов Ма Хуна и Ли Цзинвэня)}

\begin{abstract}
Аннотация: В статье на базе анализа основных произведений известных китайских ученых Ма Хуна и Ли Цзинвэня представлены научные выводы по вопросам реализации стратегии социально-экономического регионального развития КНР во второй половине XX в. по следующим направлениям: комплексной оценке политики «реформ и открытости», анализу рационализации систем управления экономикой, исследованию вопросов межрегиональной конкуренции и перспектив развития «социалистической товарной экономики». В китайской историографии вопросы стратегических социально-экономических преобразований находят отражение в монографиях экономистов, географов Ань Хусена, Ван Шэнцзина, Е. Юмин, Жэнь Баопина, Лю Вэйдуна, Сунь Цзювэня, Сунь Шанцина, У Шуцина, Цао Юйхоя, Цзин Юэцзюня, Чжан Вэньчжуна, Чжан Сяолэя и Чэн Бидина, а также на страницах таких журналов, как «Цзинцзи гуаньча» («Экономическое наблюдение»), «Чжунго гуне цзинцзи» («Промышленная экономика Китая»), «Чэнши гуйхуа» («Градостроительство»), «Цюйюй цзинцзи пинлунь» («Региональный экономический обзор»), «Гуоцзи вэньти яньцзю» («Исследования международных вопросов»), «Чжунго бяньцзян ши ди яньцзю» («Исследование истории и географии пограничных районов Китая»). Целью данной статьи стало выявление особенностей научного обоснования социальноэкономических преобразований в КНР во второй половине XX вв. китайскими учеными-экономистами Ма Хуном и Ли Цзинвэнем. Для достижения данной цели при использовании метода логического и конкретного анализа основных произведений ведущих китайских ученых-экономистов были выявлены закономерности в научном обосновании реализации стратегии социально-экономического регионального развития КНР во второй половине ХХ века.

Ключевые слова: всеобщая стратегия, научное обоснование, стратегия, развитие регионов, КНР, ученыеэкономисты, Ма Хун, Ли Цзинвэнь.

Благодарности. Исследование осуществляется при финансовой поддержке гранта РФФИ. Проект «Влияние неравномерного развития регионов России и Китая на межрегиональное двустороннее сотрудничество: сравнительно-историческое исследование» №20-014-00010.

Цитирование. Макеева С.Б. Научное обоснование стратегии регионального развития КНР во второй половине XX века (на материале работ китайских экономистов Ма Хуна и Ли Цзинвэня) // Вестник Самарского университета. История, педагогика, филология. 2020. T. 26, № 3. C. 8-15. DOI: http://doi.org/10.18287/2542-0445-2020-26-3-8-15. Информация о конфликте интересов: автор заявляет об отсутствии конфликта интересов.
\end{abstract}

S.B. Makeeva

Irkutsk State University, Irkutsk, Russian Federation E-mail: msbmag9581@yandex.ru. ORCID: https://orcid.org/0000-0003-2953-0411

\section{Scientific substantiation of the regional development strategy of the PRC in the second half of the XX century (based on the works of Chinese economists Ma Hong and Li Jingwen)}

\begin{abstract}
Based on the analysis of the main works of famous Chinese scholars Ma Hong and Li Jingwen, the article presents scientific conclusions on the implementation of the strategy of socio-economic regional development of the PRC in the second half of the XX century in the following areas: a comprehensive assessment of the policy of «reforms and openness», analysis of rationalization of economic management systems, research on inter-regional competition and prospects for the development of a «socialist commodity economy». In Chinese historiography, the issues of strategic socio-economic transformations are reflected in the monographs of various scholars of historians, economists, geographers An Husen, Wang Shenjing, Ye Yumin, Ren Baoping, Liu Weidong, Sun Jiuwen, Sun Shangqing, Wu Shuqing, Cao Yuhoy, Jing Yuejun, Zhang Wenzhong, Zhang Xiaolei and Cheng Bidin, as well as on the pages of magazines such as «Jingji Guancha» («Economic Observation»), «Zhongguo Gune Jinji» («Industrial Economy of China»), «Chengshi Guihua» («Urban Planning»), «Quuyu Jinji Pinglun» («Regional Economic review»), «Guotszi venti Yanji» («Research International»), «Zhongguo shi di byantszyan Yanji» («Study of history and geography of China's border areas»). The purpose of this article is to identify the features of the scientific justification of socio-economic transformations
\end{abstract}


in China in the second half of the XX century Chinese scholars economists Ma Hong and Li Jingwen. To achieve this goal, using the method of logical and concrete analysis of the main works of leading Chinese economists, patterns were identified in the scientific justification for the implementation of the strategy of socio-economic regional development of the PRC in the second half of the XX century. At the end of the XX century, Chinese economists in their research focused on the study of regional features of implementation of the policy of «reform and openness», while using the results of their research activities in the process of managing regional economic projects of the PRC.

Key words: general strategy, scientific justification, strategy, development of regions, China, economists, Ma Hong, Li Jingwen.

Acknowledgements. The research is carried out with the financial support of the Russian Foundation for Basic Research grant. Project «The Impact of Uneven Development of Russian and Chinese Regions on Interregional Bilateral Cooperation: A Comparative Historical Study» № 20-014-00010.

Citation. Makeeva S.B. Scientific substantiation of the regional development strategy of the PRC in the second half of the XX century (based on the works of Chinese economists Ma Hong and Li Jingwen). Vestnik Samarskogo universiteta. Istoriia, pedagogika, filologiia = Vestnik of Samara University. History, pedagogics, philology, 2020, vol. 26, no. 3, pp. 8-15. DOI: http://doi.org/10.18287/2542-0445-2020-26-3-8-15. (In Russ.)

Information on the conflict of interests: author declares no conflict of interest.

\section{ИНФОРМАЦИЯ ОБ АВТОРЕ / INFORMАТION ABOUT THE AUTHOR}

(C) Светлана Борисовна Макеева - кандидат исторических наук, ведущий научный сотрудник Института социально-политических исследований Федерального научно-исследовательского социологического центра Российской академии наук, 119991, Москва, Ленинский пр., 32А; доцент лингвистического факультета Российского государственного социального университета, 129226, Москва, Вильгельма Пика, 4, стр. 3

\section{Введение}

Пространственное региональное развитие КНР во второй половине $\mathrm{XX}$ века сопровождалось преобразованиями в территориальной организации экономической системы Китая в условиях построения плановой экономики с 1949 по 1978 год, а в период с 1978 года при внедрении рыночных отношений и формировании «социализма с китайской спецификой». Научная составляющая экономического развития КНР начиная с 1949 года была полностью подчинена решению насущных социально-экономических проблем и имела сугубо прагматический характер. Попытка установления причинно-следственных связей экономического роста КНР в конце XX века связана напрямую с комплексным анализом той теоретикометодологической базы экономических преобразований пространственного развития Китая, который был накоплен китайским обществом с момента реализации первых пятилеток при активном изучении опыта СССР, а с 1978 года - при анализе опыта экономического развития западноевропейских стран с рыночной экономикой. Вклад китайских ученых-экономистов в формирование научной основы регионального социально-экономического развития находит отражение в работах таких отечественных ученых-китаеведов, как: О.В. Борох [Борох 2017], А.В. Виноградов [Виноградов 2006], В.Я. Портяков, С.В. Степанов [Портяков, Степанов 1984].

Со времени основания Китайской Народной Республики проблемы пространственного регионального развития находили отражение в работах китайских ученых-экономистов, а также специалистов в области экономической географии. В 1950-е годы китайские экономисты и географы по примеру своих коллег - советских ученых направляли свои усилия на решение проблем реги-
(C) Svetlana B. Makeeva - Candidate of Historical Sciences, leading researcher, Institute of Socio-Political Research - Branch of the Federal Center of Theoretical and Applied SФociology of the Russian Academy of Sciences (ISPR FCTAS RAS), 32A, Leninsky prospekt, Moscow, 119991, Russian Federation; associate professor of the Linguistic Faculty, Russian State Social University, bldg. 3, 4, Wilhelm Pieck, Moscow, 129226, Russian Federation.

онального развития КНР, связанных с экономическим строительством и хозяйственным освоением разных районов Китая. В 1950-е гг. были приложены большие усилия в практическом использовании экономико-географического районирования в строительстве национальной экономики. Исследования проблем регионального развития КНР были направлены на изучение природных ресурсов и народного хозяйства страны, все результаты научной работы находили применение в крупных проектах ирригационного и дорожнотранспортного строительства.

При широком содействии СССР в первое десятилетие существования КНР применялась научно обоснованная стратегия регионального социальноэкономического развития в рамках первой пятилетки (1953-1957 гг.). Последующие годы региональных экономических преобразований дали в основном негативные результаты. Проводимый с 1979 года китайским правительством курс «урегулирования» экономики повлиял на количественное наращивание экономического потенциала, но при этом сохранились низкий уровень экономической эффективности, нерациональная структура экономики. Нехватка квалифицированных кадров и нерешенность основной задачи китайского руководства в преодолении социально-экономической отсталости регионов повлияли на необходимость разработки новых направлений региональной социально-экономической политики.

В начале 1980-х годов вопросы перспектив регионального социально-экономического развития Китая стали носить междисциплинарный характер, и постепенно к обсуждению региональных социально-экономических проблем подключались китайские ученые. Основными целями в исследовании перспектив региональноэкономического развития стали анализ законо- 
мерностей социально-экономического развития Китая, изучение опыта модернизации развитых государств, ознакомление с зарубежной теорией методологии региональных экономических преобразований, исследование региональных параметров развития территории страны, районов, а также пространственной организации экономики.

При этом китайские ученые-экономисты, специалисты в области экономической географии ориентировались в своей научной деятельности на то, чтобы китайские исследования отличались китайским своеобразием, не копировали модель «регионального развития других стран»; способствовали непрерывному совершенствованию социалистического строя; реализовывали модернизацию в целях прогресса в социально-экономическом региональном развитии.

С конца 1970-х гг. китайские исследователи начинают переводить работы зарубежных авторов, объясняющих природу рыночной экономики и последствия региональной трансформации экономического развития. В основном это были работы немецкого экономиста и социолога Альфреда Вебера (1868-1958) [Вебер 1926]; американского экономиста Эдварда Денисона (1915-1992), основателя статистического исследования экономического роста и его источников [Денисон 1975]; английского экономиста Николаса Калдора (1908-1986) - автора теории стилизованных фактов Калдора и соавтора критериев Калдора - Хикса [Калдор 1957]; немецкого географа Вальтера Кристаллера (18931969), автора теории центральных мест, в которой были указаны закономерности расположения, число и размеры населенных пунктов в иерархии городов. Широкое распространение в КНР получило применение понятия «сетка Кристаллера» [Кристаллер 1966]. У китайских ученых пользовались популярностью работы немецкого экономиста и географа Августа Лёша (1906-1945), автора теории организации экономического пространства [Лёш 2007]. А также были переведены работы известного американского ученого Уолтера Айзарда. В 1956 году он открыл в Пенсильванском университете кафедру регионоведческой науки и создал Американскую ассоциацию регионоведческой науки, которая получила международный статус. В том же году он опубликовал свою первую монографию, посвященную «науке о регионе». Впервые с работами Уолтера Айзарда китайские исследователи познакомились в 1980-е годы, когда были переведены на китайский язык основные произведения этого американского ученого. Но стоит отметить, что китайские ученые не только переводили произведения Айзарда, но и адаптировали их под китайскую действительность, дополняя примерами из региональной специфики пространственного развития КНР в тот период времени [Айзард 1975].

Целью данной статьи стало выявление особенностей научного обоснования социально-экономических преобразований в КНР во второй по- ловине XX вв. китайскими учеными экономистами Ма Хуном и Ли Цзинвэнем. Для достижения данной цели при использовании метода логического и конкретного анализа основных произведений ведущих китайских ученых-экономистов были выявлены закономерности в научном обосновании реализации стратегии социально-экономического регионального развития КНР во второй половине XX века.

Отражение стратегии социально-экономического развития КНР в работах китайского ученого-экономиста Ма Хуна

На протяжении 1979-1980-х годов в рамках обсуждения проблем регионального экономического развития среди китайских ученых-экономистов прошли дискуссии на различных симпозиумах по широкому кругу проблем теории и практики пространственного регионального экономического строительства КНР. Ведущую роль в координации научно-исследовательской деятельности китайских ученых-экономистов осуществлял президент Академии общественных наук Китая, доктор экономических наук Ма Хун (1920-2007).

Профессор Ма Хун - это один из выдающихся ученых-экономистов Китая, проводивший научные исследования региональных преобразований экономики КНР во второй половине ХХ века. Он был одним из первых, кто основал отдельное научное направление исследований «Экономика Китая». Ма Хун был не только известным ученым, но и влиятельным экономистом, управленцем высшего государственного уровня. В ходе реализации экономических проектов КНР он проводил консультации по вопросам принятия решений в процессе реализации политики реформ и открытости. В своих научных исследованиях он опирался на использование междисциплинарных подходов к анализу экономической системы КНР. На формирование научных взглядов Ма Хуна оказало влияние активное изучение экономической теории Советского Союза. В ходе участия в реализации промышленной политики на Северо-Востоке КНР в период с 1949-1960-е годы, Ма Хун занимался разработкой моделей национальной экономической реформы. После окончания «культурной революции» он продолжил научно-исследовательскую деятельность в Академии Общественных наук Китая. Ма Хун активно выступал и поддерживал рыночную реформу в Китае, а при исследовании экономического регионального развития особую роль отводил анализу «социалистической рыночной экономики». К основным направлениям научных исследований Ма Хуна необходимо отнести разработку теоретико-методологической основы структуры национальной экономики КНР, исследования процесса трансформации экономической системы Китая [Макеева 2019, с. 93-94].

Китайский ученый Ма Хун одним из первых исследователей КНР после начала «политики реформ и открытости» дает комплексную оценку ре- 
формам и перспективам развития экономики Китая в своем произведении от 1982 года «Реформы и развитие экономики Китая». Он на основе углубленного анализа экономической структуры Китая определял векторы национальных экономических преобразований. Ключевым направлением исследований у Ма Хуна являлось изучение пространственной организации экономики в период строительства четырех модернизаций. В своем произведении, анализируя экономическую структуру Китая, он выделяет некоторые аспекты регулирования национальной экономики, а также определяет темп экономических преобразований в китайском обществе, утверждая, что удовлетворение потребностей населения является высокой миссией социалистического строительства. Останавливаясь на изучении реформы системы управления экономикой КНР, Ма Хун уделяет значительное внимание «оздоровлению» плановой экономики в процессе реализации политики реформ и открытости; созданию системы экономической ответственности за преобразования в промышленном секторе. В работе «Реформы и развитие экономики Китая» он также рассматривает стратегические вопросы, касающиеся политики экономической адаптации Китая в условиях реализации «реформ и открытости». К основной стратегической задаче экономического развития КНР в 1980-е годы Ма Хун относит техническую трансформацию существующих предприятий, преобразование сектора машиностроения, развитие и комплексное планирование угольной, энергетической базы Шаньси [Ма Хун 1982, с. 212-238].

Останавливаясь на анализе Ма Хуном стратегии и перспектив экономического развития Китая, необходимо отметить, что данный китайский ученый определял ключевые факторы преобразований в КНР, начатых с 1978 года, и устанавливал значение формирования стратегии реформ пространственной организации экономики. Стратегия экономических изменений в Китае с конца 1970-х годов характеризуется Ма Хуном в русле анализа социалистической модернизации, правильного применения курса марксизма-ленинизма. Трансформация стратегии социально-экономического строительства Китая с апреля 1979 года опиралась на китайскую политику «урегулирование, преобразование, упорядочение и повышение эффективности народного хозяйства», основанную на преобразованиях социалистического экономического строительства Китая, которая, по мнению Ма Хуна, имела большое теоретическое и практическое значение.

Выход на новый путь развития социалистической экономики Китая сопровождался фундаментальными изменениями в руководстве экономической работы всего государства и состоял из двух аспектов: 1) трансформации целей стратегического развития экономики; 2) трансформации способов достижения экономических целей. Ма Хун отмечал, что стратегия экономического развития КНР должна быть направлена на удовлетворение потребностей материальной и культурной жизни людей при четком понимании основных национальных условий Китая. Пространственная организация экономики ориентировалась на создание такой экономической структуры, при которой сельское хозяйство, легкая промышленность, энергетика, добывающая промышленность, транспортная инфраструктура, торговля, сфера услуг, наука и техника были скоординированы в целях обеспечения растущих потребностей материальной и культурной жизни людей. Стратегия пространственного регионального развития КНР начиная с 1979 года ориентировалась на скоординированное развитие экономики, стабильный экономический рост и высокую эффективность преобразований. Ма Хун в работе «Реформы и развитие экономики Китая» уделял значительное внимание анализу формирования наиболее правильной стратегии экономического строительства КНР и утверждал, что без нее невозможно добиться успеха в экономических преобразованиях. Реформирование экономической структуры было нацелено на изменение серьезного дисбаланса национальной экономики Китая. Еще в 1982 году в своей работе Ма Хун отмечал, что КНР, вступая на новый путь экономического развития, достигнет экономических выгод и экономического роста и интегрирует национальную экономику в необходимом для китайского общества векторе развития.

Еще одной из фундаментальных работ китайского ученого-экономиста Ма Хуна является монография «О новой стратегии социалистического экономического развития Китая», вышедшая в свет в 1982 году. В ней он объясняет причины стратегического поворота в социалистическом экономическом развитии Китая, основные направления рационализации экономической структуры КНР и рационализацию системы управления экономикой, а также рационализацию хозяйственных организаций. Анализируя основные проблемы в области экономического строительства в Китае, Ма Хун в этой работе отмечает, что экономическое развитие КНР начиная с 1949 года было очень нестабильным. Допущение ошибок в процессе экономических преобразований пространственного регионального развития было напрямую связано с осознанием целей социалистического производства. К основным ошибкам в экономическом развитии Китая с 1949 по 1978 год Ма Хун относит: во-первых, в сфере производства и строительства одностороннее стремление к высоким показателям стоимости продукции при одновременном игнорировании экономических последствий; во-вторых, односторонний упор на развитие тяжелой промышленности, ограниченности в развитии сельскохозяйственной и легкой промышленности. Так, например, в течение первой пятилетки инвестиции в тяжелую промышленность составляли $38,7 \%$ от общего объема инвестиций, и эта доля была слишком высока, но она продолжала расти до 52,8 \% с 1958 по 1978 год. В течение этого 
периода сельскохозяйственное производство развивалось медленно. В-третьих, расширение воспроизводства опиралось исключительно на новые инфраструктурные проекты, игнорируя в полной мере роль первоначальных предприятий и не обращая внимания на технологические преобразования. В-четвертых, выпуск основных продуктов тяжелой промышленности, таких как стали, привел к тому, что товары народного потребления, в которых нуждалось население, были в дефиците. Данные ошибки, по мнению Ма Хуна, обостряли проблемы пространственного регионального развития КНР во второй половине ХХ века [Ма Хун 1982, с. 127-130].

В 1984 году Ма Хун публикует еще одну свою известную работу - «Структура экономики и управление экономикой», в которой подробно анализирует структуру китайской экономики, процесс управления китайской экономикой, научные основы управления экономикой, проводит сравнительный анализ данных процессов в развитых странах. Рассматривая реформирование экономической структуры Китая, Ма Хун ориентируется на изучение основных направлений социалистической модернизации с китайской спецификой; оценку научных подходов по совершенствованию экономической структуры Китая; изучение некоторых аспектов модернизации народного хозяйства; комментирование основных положений долгосрочного планирования пространственной экономики Китая. К основным вопросам в изучении управления пространственной организации экономики Ма Хун относит: проблемы управления промышленным хозяйством, вопросы региональной конкуренции в условиях социалистической экономики, проблемы подготовки кадров в области экономического управления, некоторые аспекты экономических исследований капиталистического строительства. При изучении проблем пространственного регионального развития Китая Ма Хун отводит значительное место количественной экономике, которая помогала, по мнению ученого, в социалистическом строительстве КНР [Ма Хун 1984, c. 301-312].

В работе Ма Хуна «Товарное хозяйство в условиях социалистического строя», которая была опубликована в Шанхае в 1985 году, представлены изменения в понимании роли товаров в условиях социализма, предложена характеристика социалистического товарного хозяйства. Ма Хун отмечает, что социалистическая экономика - это плановая, качественная экономика, основанная на общественной собственности. Социалистическая экономика является в определенной степени товарной экономикой. Как отмечает ученый, исследования социалистической товарной экономики выступают теоретической основой для проведения реформы экономической системы и реализации политики оздоровления экономики и открытости внешнему миру [Ма Хун 1985, с. 5-62].
Оценивая значение его научной деятельности в области исследования проблем пространственного регионального развития КНР, необходимо отметить, что Ма Хун - это не только ученый, который ранее предлагал и поддерживал аргументы «социалистической товарной экономики» и «социалистической рыночной экономики», но и активный практический сторонник рыночных реформ в Китае. Примерно в 1991 году научная общественность вновь начинает дискуссии по вопросам планирования и рыночных вопросов в социалистической экономике. Труд Ма Хуна «Построение новой системы социалистической рыночной экономики» был опубликован публично, систематически отражая некоторые важные идеи о создании социалистической рыночной экономической системы в Китае.

\section{Научные взгляды китайского ученого- экономиста Ли Цзинвэня по вопросам регио- нального развития КНР во второй половине XX века}

Еще одним выдающимся китайским ученым в области экономики и инженерного менеджмента второй половины XX века является Ли Цзинвэнь (1932), который в своих работах так же, как и Ма Хун, использовал междисциплинарный подход в анализе проблем пространственного регионального развития КНР. Ли Цзинвэнь окончил Московский государственный экономический институт. Длительный период времени продолжал свою научную карьеру в качестве научного сотрудника Института количественной и технологической экономики, совмещал работу с должностью декана института менеджмента и управления экономикой Пекинского политехнического университета, являлся председателем Китайского научного общества проектирования экономических и социальных систем. Ли Цзинвэнь входил в состав Китайской Академии общественных наук КНР, а также являлся председателем Китайского общества инженеров. Данный ученый исследовал проблемы устойчивого территориального развития и регионального планирования КНР. Ли Цзинвэнь был одним из первых исследователей в Китае в области технической экономики и теории производственного управления. Им разработана теоретикометодологическая база технико-экономического обоснования строительства промышленных объектов в соответствии с региональной действительностью Китая. Используя научные методы в рамках изучения китайской экономики на основе среднесрочных и долгосрочных прогнозов, а также структуры промышленности и регионального развития, он принимал научно обоснованные решения и возглавлял процесс технико-экономического обоснования таких крупномасштабных проектов, как программа по комплексному решению проблем Янцзы и освоению энергетических ресурсов реки (проект Санься), проект КНР по мелиорации засушливых северных земель за счет водных ре- 
сурсов южных рек (проект переброски вод Янцзы в северные районы Китая), проект высокоскоростной железной дороги Пекин - Шанхай [Макеева 2019, с. 94].

Ли Цзинвэнь взял на себя ведущую роль в определении методов измерения научно-технического прогресса и на этой основе изучил структуру промышленности Китая и региональные экономические проблемы, входил в группу разработки и контроля над проектами стратегического планирования регионального экономического развития провинций Китая. Он исследовал закономерности развития региональной экономической системы Китая. Его основными принципами научной деятельности являлись ориентация на практическое применение результатов исследований, использование инноваций в рамках планирования региональной экономической политики КНР. Ли Цзинвэнь изучал влияние научно-технического прогресса на региональное развитие Китая, осуществлял качественный и количественный анализ экономической ситуации в разных районах КНР, прогнозировал и реализовывал инженерные региональные проекты, принимал участие в управлении процессами использования природных ресурсов и устанавливал степень воздействия промышленных преобразований на окружающую среду Китая. На основе использования методов измерения научно-технического прогресса он изучал региональную промышленную структуру Китая и выявлял региональные экономические проблемы. Ли Цзинвэнь принимал активное участие в таких научно-исследовательских проектах, как «Экономический прогноз развития Китая с 1998-2050 годы», «Исследования устойчивого развития старых промышленных баз КНР», «Пекинский экономический рост и оптимизация производственных структур», «Производительность и экономический рост в Китае, США и Японии». К основным направлениям научных исследований Ли Цзинвэня необходимо отнести: структуру производства и технологический прогресс; анализ экономического положения Китая и прогноз развития; прогноз экономического развития Китая с 1996 по 2010 год; прогноз экономического развития Китая на 1998-2050 годы; производительность и экономический рост Китая; комплексные исследования методов экономического роста; структурную оптимизацию производства и экономический рост Пекина (1996-2010); экономический анализ ископаемых ресурсов и политику по реализации стратегии устойчивого развития; экономические проблемы в процессе урбанизации; исследования законодательства и политических мер по стратегии устойчивого развития нефтегазовых ресурсов Китая; исследование региональных экономических проблем; исследование региональных процессов возрождения старых промышленных баз; оценку проекта управления водными ресурсами; исследование инновационной модели развития, техноло- гических новшеств в развитии китайских железных дорог.

Проблемы пространственного регионального развития КНР во второй половине ХХ века Ли Цзинвэнь рассматривает в работе «Обогащение государства научными технологиями», вышедшей в свет в Пекине в 2001 году. Анализируя систему разделения отдельных провинций и автономных районов КНР с учетом среднегодовых темпов роста национального дохода и роста промышленного производства в период с конца 1970-х до 1990-х годов, предложенную Ли Цзинвэнем, необходимо отметить, что темпы роста в 28 провинциях, автономных районах по всей стране условно можно разделить на следующие три категории с учетом темпов регионального развития до и после начала политики реформ и открытости.

1-я группа включает в себя Пекин, Тяньцзинь, Шанхай, Ляонин, Хэйлунцзян, Шэньси, Цинхай, Нинся-Хуэйский автономный район, а также отдельные города и районы. После начала политики реформ и открытости среднегодовые темпы роста национального дохода были снижены, чем в среднем по стране. Но, несмотря на то что среднегодовые темпы роста национального дохода Шэньси и Нинся-Хуэйского автономного района ускорились после реформ и открытости, среднегодовые темпы промышленного роста были ниже, чем средние темпы роста по стране. Следует отметить, что в соответствии с географическим положением Шанхая, уровнем социально-технического развития данный город центрального подчинения должен быть отнесен ко второй группе, но поскольку он являлся важной промышленной базой в период политики реформ и открытости в Китае, то по экономическому региональному развитию был отнесен к 1-й группе.

2-я группа объединяет Цзянсу, Чжэцзян, Аньхой, Фуцзянь, Шаньдун, Гуандун, Юньнань. Среднегодовые темпы прироста национального дохода и роста промышленного производства до начала периода политики реформ и открытости в этом регионе были ниже, но после начала реформы объем чистого промышленного производства и среднегодовые темпы роста национального дохода ускорились, что привело к росту национального дохода этих провинций и автономных районов.

3-я группа включает Хэбэй, Шаньси, автономный район Внутренняя Монголия, Цзилинь, Цзянси, Хэнань, Хубэй, Хунань, Гуанси-Чжуанский автономный район, Сычуань, Гуйчжоу, Ганьсу. Хотя среднегодовые темпы роста национального дохода в этих районах ускорились после начала политики реформ и открытости, но до периода реформ среднегодовые темпы роста в основном были средними по стране. Так, например, в четырех административных единицах КНР: Шаньси, автономном районе Внутренняя Монголия, Хунани и Гансу до начала политики реформ и открытости среднегодовые темпы роста промышленной продукции 
были выше, чем средние темпы роста по стране [Ли Цзинвэнь 1995, с. 23-71, с. 453-496].

Ли Цзинвэнь выявляет закономерности между технологическим прогрессом и экономическим ростом, влиянием технологического прогресса на структуру промышленности, воздействием научно-технического прогресса на региональное развитие, на политику открытости, на развитие рыночной экономики, а также в своей работе определяет перспективы научно-технического прогресса в развитии Китая.

Большинство работ Ли Цзинвэня посвящены сравнительному анализу пространственной организации экономики в КНР и других странах мира, но в основном ученый проводит сопоставительный анализ региональных экономических процессов в Китае, Японии, США и России. В 1993 году в Пекине вышла в свет работа Ли Цзинвэня «Исследование производительности и экономического роста Китая, США и Японии», в которой на основе детального анализа теоретико-методологических основ производительности, изучения концепции продуктивности, анализа статистических данных, анализа методов стоимостной оценки выделяются основные направления производственноэкономического роста Китая. Ли Цзинвэнь подробно останавливается на рассмотрении анализа общего экономического роста Китая, выделении факторов экономического роста, динамике роста объемов производства в Китае, измерении и анализе капиталовложений, выявлении экономических выгод от инвестиционных вложений, прогнозировании повышения производительности и качественном росте в КНР. Далее Ли Цзинвэнь по данным параметрам анализа проводит исследование производительности и экономического роста в Японии, США в сопоставительном аспекте с региональным экономическим развитием Китая [Ли Цзинвэнь 1993, с. 18-27].

Среди основных публикаций Ли Цзинвэня необходимо выделить работу «Стратегия экономического развития Китая в XXI веке», которая была опубликована в Пекине в 2001 году. В ней содержится углубленный сравнительный анализ исторической эволюции экономической стратегии США, Европейского Союза, Японии, России и Китая. Ли Цзинвэнем выделяются факторы развития политической экономии, перспективы прогнозирования будущего экономического развития Китая. Как утверждает Ли Цзинвэнь, исследование экономик крупнейших мировых держав и их стратегий развития необходимо для того, чтобы китайское правительство могло своевременно принимать меры для поддержания быстрого экономического развития Китая [Ли Цзинвэнь 2001, с. 27-32].

\section{Заключение}

Таким образом, в ходе проведения политики «реформ и открытости» с 1978 года в КНР возрастает интерес к западноевропейским и американским теориям регионального развития, объясня- ющим влияние рыночных отношений на процессы территориальных региональных преобразований в государстве. Одним из выдающихся ученыхэкономистов Китая, внесших весомый вклад в проведение научных исследований региональных преобразований экономики КНР, являлся Ма Хун, теоретик и практик экономики, управленец высшего государственного уровня. В ходе управления экономическими проектами КНР Ма Хун принимал участие в проведении экономических консультаций по вопросам принятия решений в процессе реализации политики «реформ и открытости». В своих научных исследованиях он опирался на использование междисциплинарных подходов к анализу экономической системы КНР. На формирование научных взглядов Ма Хуна оказало влияние активное изучение экономической теории Советского Союза. Еще одним из выдающихся китайских ученых в области экономики и инженерного менеджмента во второй половине XX века являлся Ли Цзинвэнь. Исследователь-практик, который объяснял природу регионального развития экономической системы Китая. Его основными принципами научно-исследовательской деятельности выступала ориентация на практическое применение результатов научной деятельности, использование инноваций в рамках реализации экономической региональной политики КНР. Ли Цзинвэнь входил в состав Китайской Академии общественных наук КНР и являлся председателем Китайского общества инженеров по экономической и социальной системам. Данный ученый выступал теоретиком и практиком устойчивого территориального развития и регионального планирования КНР. В конце ХХ века китайские ученые-экономисты в своих научных исследованиях ориентировались на изучение региональных особенностей реализации политики «реформ и открытости», при этом использовали результаты своей научно-исследовательской деятельности в процессе управления региональными экономическими проектами КНР. При содействии Ма Хуна, Ли Цзинвэня в 1980-90-е годы в Китае получает распространение научная школа пространственного экономического анализа, в рамках которой рассматривались основные проблемы, связанные с пространственной организацией экономики Китая в условиях построения «социализма с китайской спецификой».

\section{Библиографический список}

Айзард 1975 - Айзард У. Введение в региональную науку. Прентис-Холл, 1975. С. 506.

Борох 2017 - Борох О.В. Ван Янань и концепциия «китайской экономической науки» // Проблемы Дальнего Востока. 2017. № 1. С. 72-84. URL: https:// elibrary.ru/item.asp?id=28916017.

Вебер 1926 - Вебер A. Теория размещения промышленности. Ленинград; Москва, 1926. 223 с. 
Виноградов 2006 - Виноградов А.В. К методологии изучения китайской модернизации // Проблемы Дальнего Востока. 2006. № 2. C. 115-127. URL: https:// elibrary.ru/item.asp? $\mathrm{id}=9251425$.

Денисон 1975 - Денисон Э. Источники экономического роста в США и альтернативы перед США. Москва: Прогресс, 1975. 112 с.

Калдор 1957 - Калдор Н. Модель экономического роста // Экономический журнал. 1957. Т. 67. С. 591-624.

Кристаллер 1966 - Кристаллер В. Центральные места на юге Германии. Нью Джерси: Энглвудские скалы, 1966. $230 \mathrm{c}$.

Лёш 2007 - Лёш А. Пространственная организация хозяйства. Москва: Наука, 2007. 664 с. URL: https:// elibrary.ru/item.asp?id=19843734.

Ли Цзинвэнь 1995 - Ли Цзинвэнь. 科技富国论 Обогащение государства научными технологиями. Пекин, 1995. 496 с.

Ли Цзинвэнь 1993 - Ли Цзинвэнь. 生产率与中美日 经济增长研究 $=$ Исследование производительности и экономического роста Китая, США и Японии. Пекин, $1993.532 \mathrm{c}$

Ли Цзинвэнь 2001 - Ли Цзинвэнь. 21世纪的中国经 济发展战略 = Стратегия экономического развития Китая в XXI веке. Пекин, 2001. 354 с.

Макеева 2019 - Макеева С.Б. Вклад ученыхэкономистов Ли Цзинвэня, Ма Хуна в китайские регионоведческие исследования второй половины XX века // XXX Международный конгресс по источниковедению и историографии стран Азии и Африки: к 150-летию академика В.В. Бартольда (1869-1930) 19-21 июня 2019 г.: материалы конгресса. Санкт-Петербург, 2019. С. 93-94. URL: https://elibrary.ru/item.asp?id=40643663.

Макеева 2019 - Макеева С.Б. Проблемы регионального развития КНР в работах китайских ученыхэкономистов // Россия и Китай: история и перспективы сотрудничества: материалы VIII Международной науч.практ. конф. Благовещенск: БГПУ, 2019. С. 101-106. URL: https://elibrary.ru/item.asp?id=37608446.

Ма Хун 1984 - $M a$ Хун. 经济结构与经济管理 = Структура экономики и управление экономикой. Пекин, 1984. $333 \mathrm{c}$.

Ма Хун 1982 - Ма Хун. 中国经济调整改革与发展 $=$ Реформы и развитие экономики Китая. Шаньси, 1982. $404 \mathrm{c}$.

$\mathrm{Ma}$ Хун $1982-M a X y \mu$. 试论我国社会主义经济发 展的新战略 $=\mathrm{O}$ новой стратегии социалистического экономического развития Китая. Пекин, 1982. 134 с.

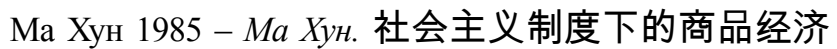
= Товарное хозяйство в условиях социалистического строя. Шанхай, 1985. 69 с.

Портяков, Степанов 1984 - Портяков В.Я., Cтепанов C.B. Ученые КНР о стратегии социальноэкономического развития страны // Проблемы Дальнего Востока. 1984. № 3. С. 35-47.

\section{References}

Isard 1975 - Isard W. (1975) Introduction to Regional Science. Prentice Hall, 506 p. (In Russ.)

Borokh 2017 - Borokh O.V. (2017) Wang Yanan and the concept of «Chinese economic science». Far Eastern
Affairs, no. 1, pp. 72-84. Available at: https://elibrary.ru/ item.asp?id=28916017. (In Russ.)

Weber 1926 - Weber A. (1926) Theory of Industrial Placement. Leningrad - Moscow, 223 p. (In Russ.)

Vinogradov 2006 - Vinogradov A.V. (2006) On the methodology of studying Chinese modernization. Far Eastern Affairs, no. 2, pp. 115-127. Available at: https:// elibrary.ru/item.asp?id=9251425. (In Russ.)

Denison 1975 - Denison E.F. (1975) The Sources of Economic Growth in the United States and the Alternatives before Us, the Committee for Economic Development. Moscow: Progress, 112 p. (In Russ.)

Kaldor 1957-Kaldor N. (1957) Model of economic growth. Ekonomicheskii zhurnal, vol. 67, pp. 591-624. (In Russ.)

Christaller 1966 - Christaller W. (1966) Central places in the south of Germany. New Jersey: Englvudskie skaly, 1966, 230 p. (In Russ.)

Lyosh 2007 - Lyosh A. (2007) Spatial organization of the economy. Moscow: Nauka, 2007, 664 p. Available at: https://elibrary.ru/item.asp?id=19843734. (In Russ.)

Li Jingwen $1995-$ Li Jingwen (1995) 科技富国论 = State enrichment with scientific technologies. Peking, 496 p. (In Chinese.)

Li Jingwen 1993 - Li Jingwen (1993) 生产率与中美日经 济增长研究= Productivity and Economic Growth Study of China, the USA and Japan. Peking, 532 p. (In Chinese.)

Li Jingwen 2001 - Li Jingwen (2001) 21世纪的中国经济 发展战略= China Economic Development Strategy for the XXI century. Peking, 2001, 354 p. (In Chinese).

Makeeva 2019 - Makeeva S.B. (2019) Contribution of economists $\mathrm{Li}$ Jingwen and $\mathrm{Ma}$ Hong to Chinese regional studies of the second half of the XX century. In: XXX International Congress on Source Studies and Historiography of Asian and African Countries: on the 150th anniversary of Academician V.V. Bartold (18691930) June 19-21, 2019: congress materials. Saint Petersburg, 2019, pp. 93-94. Available at: https://elibrary. $\mathrm{ru} / \mathrm{item} . \mathrm{asp}$ ?id=40643663. (In Russ.)

Makeeva 2019 - Makeeva S.B. (2019) Problems of regional development of the China in the works of Chinese scientistseconomists. In: Russia and China: history and prospects of cooperation: materials of the VIII International research and practical conference. Blagoveshchensk: BGPU, 2019, pp. 101-106. Available at: https://elibrary.ru/item. asp?id=37608446. (In Russ.)

Ma Hong 1984 - Ma Hong (1984) 经济结构与经济管理 $=$ Structure of the economy and economic management. Peking, 333 p. (In Chinese.)

Ma Hong 1982 - Ma Hong (1982) 中国经济调整改革与 发展 = Reforms and development of the Chinese economy. Shanxi, 404 p. (In Chinese.)

Ma Hong 1982 -Ma Hong (1982) 试论我国社会主义经济 发展的新战略 = On the new strategy of socialist economic development of China. Peking, 1982, 134 p. (In Chinese.)

Ma Hong 1985 - Ma Hong (1985) 社会主义制度下的 商品经济 = Commodity economy in a socialist system. Shanghai, 69 p. (In Chinese.)

Portyakov, Stepanov 1984 - Portyakov V.Ya., Stepanov S.V. (1984) Chinese scientists on the strategy of socio-economic development of the country. Far Eastern Affairs, no. 3, pp. 35-47. (In Russ.) 